\title{
MOLECULAR-GENETIC ASPECTS OF KABUKI MAKEUP SYNDROME. Review
}

\author{
${ }^{1}$ Lastivka I.V. https://orcid.org/0000-0002-9088-1301 \\ ${ }^{2}$ Antsupva V.V. https://orcid.org/0000-0002-7849-2602 \\ ${ }^{1}$ Babintseva A.H. https://orcid.org/0000-0002-3859-6431 \\ ${ }^{3}$ Unhurian M.D. https://orcid.org/0000-0002-8385-6176 \\ ${ }^{2}$ Ushko I.A https://orcid.org/0000-0003-3017-7766 \\ ${ }^{1}$ Bukovinian State Medical University, Chernivtsi, Ukraine \\ ${ }^{2}$ Bogomolets National Medical University, Kyiv, Ukraine \\ ${ }^{3}$ Chernivtsi Regional Perinatal Center, Chernivtsi, Ukraine \\ antsupovavita@gmail.com
}

Relevance. Kabuki Makeup Syndrome (KS) is a rare monogenic genetic disease characterized by multiple malformations. The phenotype includes specific facial features, skeletal and dermatoglyphic abnormalities, mental retardation, short stature. Most cases are associated with de novo mutations in the KMT2D and KMD6A genes. However, in $25 \%$ of patients with KS, the genetic basis remains unknown, which indicates the genetic heterogeneity of the disease and encourages further accumulation of clinical experience in KS. The article summarizes current data on the molecular genetici aspects of the development of Kabuki Makeup Syndrome and describes its own clinical case of Kabuki Makeup Syndrome Type I.

Objective: to summarize the data on modern molecular-genetic aspects of the development of Kabuki makeup syndrome on the example of a clinical case.

Materials and methods. Analysis of scientific publications in the international electronic scientometric database Scopus, PubMed by keywords. Search depth - 15 years (2007-2021). The clinical case of Kabuki Makeup Syndrome from our own practice. Clinical and genealogical, molecular-genetic, cytogenetic, instrumental research methods.

Results. According to current data, the development of Kabuki Makeup Syndrome is due to mutations in the KMT2D (MLL2) gene, which belongs to the genes that control embryogenesis. KMT2D functions as a promoter of the expression of other genes and the KDM6A gene; encodes a large multidomain protein that interacts with the SET1/COMPASS complex. KDM6A is a cofactor physically associated with the KMT2D-COMPASS complex and exhibits demethylase activity in histone 3. Gene mutations KMT2D and KDM6A associated with KS lead to a lack of functioning of the corresponding enzyme, which leads to impaired methylation of histones and active genes in many organs and tissues of the body. Depending on the type of mutation in the KMT2D and KMD6A genes, there are two types of Kabuki Makeup Syndrome. KS type 1 with autosomal dominant type of inheritance due to pathogenic mutations in the KMT2D gene in a heterozygous state on chromosome 12q13.12. 70\% of patients have KS1. Type $2 \mathrm{KS}$ is an X-linked disease that develops as a result of a heterozygous pathogenic mutation in the KDM6 gene. In most cases, KS mutations are sporadic, but families with parent-to-child transmission have been described. In patients with phenotypic signs of KS pathogenic mutations are detected in $75 \%$ of cases. Pathogenic mutations in the KMT2D gene can be detected in mosaic form, and the carrier can pass this mutation on to offspring. Pathogenic mutations have not been described in phenotypically healthy people.

Here is our own observation. The girl with a combined congenital heart defect and multiple stigmas of dysembryogenesis was born at 36 weeks with a weight of 2930, $49 \mathrm{~cm}$ long, on the Apgar scale 8/8 points from the third planned pregnancy in parents who already had an older healthy boy. In connection with multiple malformations, the girl underwent a syndromic diagnosis using the program «Face2 gene»; Kabuki Makeup Syndrome is suspected. Molecular genetic analysis revealed a pathogenic mutation (c.11884C>T) (p.Gln3962*) in the KMT2D gene, which is associated with autosomal dominant Kabuki Makeup Syndrome of type 1 (MedGen UID: 893727).

Conclusions. Kabuki Makeup Syndrome has clinical and molecular polymorphisms. Most of the registered KMT2D mutations occur de novo and occur in episodic cases. The described case demonstrates the molecular-positive Kabuki Makeup Syndrome of type I. The identified variant $c .11884 C>T($ p. Gln3962*) in the KMT2D gene is associated with the autosomal dominant Kabuki Makeup Syndrome (MedGen UID: 893727). Verification of the diagnosis of the disease and prevention of KS in siblings is based on the results of molecular genetic analysis. The prognosis of this disease depends on the severity of heart disease and intellectual impairment. Early diagnosis determines the type and timing of therapeutic interventions, is crucial for medical and genetic counseling of the family.

Key words: Kabuki Makeup Syndrome, specific facial features, KMT2D and KMD6A genes mutations.

Relevance. Kabuki Makeup Syndrome (KS) or Niikawa-Kuroki Syndrome (OMIM 147920) is a rare genetic disease characterized by phenotypic traits, speech retardation, and autistic symptoms. The syndrome was first described by Japanese doctors N. Niikawa et al. and Y. Kuroki et al. in 1981. They identified the main clinical and phenotypic features: specific facial features, skeletal abnormalities, mental retardation, growth deficit, dermatoglyphic abnormalities. Due to the presence of phenotypic facial features that resemble the appearance of actors of the Kabuki Theater, the disease was called «Kabuki Makeup Syndrome». The prevalence of KS in Japan is 1:32 000, in Western countries - 1:86 $000[1,2]$. The onset of the syndrome is associated with mutations in the KMT2D and 
$K M D 6 A$ genes. Pathogenic and non-pathogenic mutations in the $K M T 2 D$ and $K D M 6 A$ genes have been described in the literature [3]. In patients with phenotypic signs of KS pathogenic mutations are detected in $75 \%$ of cases. Pathogenic mutations have not been described in phenotypically healthy people. Small deletions or insertions, nonsense and missense mutations, shift of the reading frame are described as the reason of development of the disease, some of them are pathogenic, some of them are of unknown clinical significance. In $25 \%$ of patients with $\mathrm{KS}$, the genetic basis remains unknown, which indicates the genetic heterogeneity of the disease and encourages further accumulation of clinical experience [4-8].

Objective: to summarize the data on modern molecular-genetic aspects of the development of Kabuki makeup syndrome on the example of a clinical case.

\section{MATERIALS AND METHODS}

Analysis of scientific publications in the international electronic scientometric database Scopus, PubMed by keywords. Search depth -15 years (2007-2021). The clinical case of Kabuki Makeup Syndrome from our own practice. Clinical and genealogical, molecular-genetic, cytogenetic, instrumental research methods.

\section{RESULTS AND DISCUSSION}

According to current research, the etiopathogenesis of the disease is associated with mutations in the KMT2D gene (also known as MLL2), which belongs to the family of mixed-cell leukemia genes required for embryogenesis and functions as a promoter of other genes and the KDM6A gene. KMT2D encodes a large multidomain protein that interacts with the SET1/COMPASS complex. $K D M 6 A$ is a cofactor physically associated with the KMT2D-COMPASS complex and exhibits demethylase activity in histone 3 . Together, the components of the KMT2D-COMPASS complex remove inhibitory epigenetic labels and add activating labels, namely mono-, di- or trimethylation of histone 3. Depending on the type of mutation in the genes that cause KS, there are two types: KS type 1 with autosomal dominant (AD) type of inheritance, which is caused by heterozygous pathogenic mutations in the KMT2D gene on chromosome $12 q 13.12$ and KS type $2-X$-linked disease that develops as a result of a heterozygous pathogenic mutation in the KDM6 gene. In most patients (70 \%) register KS1. Gene mutations KMT2D and KDM6A associated with KS, lead to a lack of functioning of the corresponding enzyme, which leads to impaired methylation of histones and activation of specific genes in many organs and tissues of the body. In most cases, KS mutations are sporadic, but families with parent-to-child transmission have been described. Pathogenic mutations in the KMT2D gene can be detected in a mosaic form, and the carrier can pass this mutation to offspring $[4,5,8-11]$.
Various cytogenetic abnormalities have been described in patients with clinically established KS, which includes an annular X chromosome, translocations, inversions, duplications $[8,10,11]$.

At KS there are mutations-negative and mutations-positive patients. Phenotypic signs of the disease in mutation-negative and mutation-positive patients do not different $[4,8,10,11]$.

The phenotype of children with KS includes microcephaly, arched eyebrows with thickening to the center/ thinning of the lateral part, wide nose, hypertelorism, elongated eye slits, antimongoloid incision of the eyes, long thick eyelashes, ectropion of the lateral part of the lower eyelid and short, short low-set auricles, micrognathia, thin upper lip, gothic palate and/or cleft palate, abnormalities of the teeth with the formation of a false bite, low hair growth on the back of the head, hyperelastic skin, hirsutism, skin pigmentation disorders, nail dysplasia [ 1-3,6].

Among the skeletal anomalies in KS, the most common are anomalies of the sutures of the skull, spine and vertebrae, shoulders and ribs, hands, dislocations/subdislocations of the joints. KS is characterized by postnatal growth retardation that develops during the first years of life. By 6-10 years, some patients develop obesity. Delayed speech development in patients with KS occurs in $100 \%$ of cases. Intellectual deficit from mild to moderate. Cases of autism-like behavior in children with KS have been described. Among neurologic displays muscular hypotension, coordinating disturbances, a delay of development of stato-kinetic skills can be observed. Neuroimaging reveals ventriculodilation of the lateral ventricles, hypoplasia of the corpus callosum, hypoplasia of the adenohypophysis. Seizures occur in 36-45 \% of cases at any age, more often in girls. Ophthalmic findings include ptosis, strabismus, nystagmus, paralysis of the afferent nerve, microphthalmia. Features of dermatoglyphics - high fetal pads on the fingertips, increasing the ulnar radius, increasing the radius of the hypotenuse, the absence of the finger triradius - the only difficult on the palm. With corticosteroids can be defects of the kidneys and urinary tract, genitals, gastrointestinal tract, ENT organs, cardiovascular system, various hernias. In 40-50\% of cases, congenital heart defects (CHD) are diagnosed (defects in the valves or membranes of the heart, coarctation of the aorta, transposition of large vessels). Children with SK are prone to bronchopulmonary diseases with a prolonged course. Endocrine pathology is represented by hypothyroidism, diabetes, hypoglycemia or diabetes mellitus, late puberty, pituitary dwarfism. At KS the immune status is broken. There is a decrease in serum immunoglobulin classes (80 \% - IgA deficiency), due to the fact that the genes $K M T 2 D$ and $K D M 6 A$ are involved in epigenetic regulation and affect the development of immunocompetent cells [1-3, 6-9].

Here is our own observation of early diagnosis of KS in a child. Girl O., born in 2019, was born from the third 
desired and planned pregnancy, which took place against the background of the threat of miscarriage, polyhydramnios, hypothyroidism. The older brother is healthy from the first pregnancy. The second pregnancy ended in miscarriage in early pregnancy. The third pregnancy occurred against the background of drugs that promote conception. ATC in the fetus was diagnosed at 20 weeks of gestation.

Heredity through the mother is burdened with cardiovascular and oncopathological pathology; great-grandmother on the mother's line suffers from diabetes. Heredity on the paternal line is burdened by oncopathology; grandfather suffers from diabetes. Both parents suffer from hypothyroidism.

The baby was born at 36 weeks of gestation with a weight of 2930, length $49 \mathrm{~cm}$, Apgar scale 8/8 points. Due to severe congenital heart disease (CHD), immediately after birth, the child was transferred to the Department of Pediatric Cardiology and Cardiac Surgery in Kyiv for examination and surgical treatment. Parents refused surgical treatment after reviewing the possible risks of surgical treatment and long-term prognosis. The child was transferred to the neonatal pathology department in Chernivtsi. The condition on admission was considered severe, which was due to the combined CHD and feeding problems. She was fed through a tube. Reflexes are suppressed, the tone of muscles is lowered. The crack of a soft palate is noted. Tissue turgor is reduced. Heart tones are rhythmic, loud, systolic murmur along the left edge of the sternum. The abdomen is soft, painless on palpation. The liver protrudes $2 \mathrm{~cm}$ from under the costal arch. Defecation without abnormalities.

The child was consulted by a geneticist, revealed multiple developmental abnormalities (CHD, cleft palate, protruding ear shells, arched eyebrows, long oblique eye slits, blue sclera, epicanthus, ectropion of the lower eyelids, wide tip of the nose, hand, hypothyroidism), dysplasia of the hip joints, muscular hypotension, delayed stato-kinetic development. Syndromological diagnostics was performed using the diagnostic program «Face2gene»; Kabuki Makeup Syndrome is suspected; molecular genetic testing is recommended to verify the diagnosis. Molecular genetic analysis revealed a pathogenic mutation $(c .11884 C>T)\left(p . G \ln 3962^{*}\right)$ in the KMT2D gene, which is associated with autosomal dominant Kabuki Makeup Syndrome of type 1 (MedGen UID: 893727).

The child is offered registration of the status «Child with a disability»; observation in dynamics by a pediatric cardiologist, pediatric neurologist and geneticist is recommended.

\section{CONCLUSIONS}

Kabuki Makeup Syndrome has clinical and molecular polymorphisms. Most of the registered KMT2D mutations occur de novo and occur in episodic cases. The described case demonstrates the molecular-positive Kabuki Makeup Syndrome of type I. The identified variant c. $11884 C>T($ p.Gln3962*) in the KMT2D gene is associated with the autosomal dominant Kabuka makeup syndrome (MedGen UID: 893727). Verification of the diagnosis of the disease and prevention of KS in siblings is based on the results of molecular genetic analysis. The prognosis of this disease depends on the severity of heart disease and intellectual impairment. Early diagnosis determines the type and timing of therapeutic interventions, is crucial for medical and genetic counseling of the family.

\section{REFERENCES}

1. Jones KL. Smith's recognizable patterns of human malformation, 8th edition. Elsevier, 2021. 1088 p. View at: Scopus: https://www.elsevier.com/books/ smiths-recognizable-patterns-of-human-malformation/ jones/978-0-323-63882-1

2. Kozlova SI, Demikova NS. Hereditary syndromes and medical genetic counseling, 3th edition. KMK Scientific Publishing Partnership, 2007; 447: 93-94. View at: Publisher Site: https://medkniga.com. ua/15726-nasledstvennie-sindromi-i-mediko-geneticheskoe-konsultirovanie-atlas-spravochnik-3-e-izd/

3. Kabuki syndrome-1. OMIM: 147920. Mendelian inheritance in humans online. McKusick-Nathans Institute of Genetic Medicine, John Hopkins University, National Center for Biotechnology Information. National Medical Library.

View at: Publisher Site: https://www.omim.org/ entry/147920?search=Kabuki\&highlight=kabuki

4. Maas NMC, Van de Putte T, Melotte C, Francis A, Schrander-Stumpel C, Sanlaville D, Genevieve D, Lyonnet S, Dimitrov B, Devriendt K, Fryns J-P, Vermeesch JR. The C20orf133 gene is disrupted in a patient with Kabuki syndrome. J Med Genet. 2007;44(9):562-9. DOI: 10.1136/jmg.2007.049510 View at: Publisher Site: https://jmg.bmj.com/ content/44/9/562

PubMed: https://pubmed.ncbi.nlm.nih.gov/17586838/ PubMed Central: https://www.ncbi.nlm.nih.gov/pmc/ articles/PMC2597955/

5. Zarate YA, Zhan H, Jones JR. Infrequent Manifestations of Kabuki Syndrome in a Patient with Novel MLL2 Mutation. Mol Syndromol. 2012;3(4):180184 DOI: $10.1159 / 000342253$

View at: Publisher Site: https://www.karger.com/ Article/FullText/342253

PubMed: https://pubmed.ncbi.nlm.nih.gov/23239960/ PubMed Central: https:/www.ncbi.nlm.nih.gov/pmc/ articles/PMC3507269/

6. Carosso GA, Boukas L, Augustin JJ, Nguyen HN, Winer BL, Cannon GH, Robertson JD, Zhang L, 
Hansen KD, Goff LA, Bjornsson Hans T. Precocious neuronal differentiation and disrupted oxygen responses in Kabuki syndrome. JCI Insight. 2019 Oct 17; 4(20): e129375. DOI: 10.1172/jci.insight. 129375 View at: Publisher Site: https://insight.jci.org/ articles/view/129375

PubMed: https://pubmed.ncbi.nlm.nih. gov/31465303/

PubMed Central: https://www.ncbi.nlm.nih.gov/pmc/ articles/PMC6824316/

7. Olney AH, Schaefer GB, Kolodziej P. Kabuki Syndrome. Ear, Nose \& Throat Journal. 1998 Sep;77(9):734

View at: Publisher Site: https://journals.sagepub. com/toc/eara/77/9

PubMed: https://pubmed.ncbi.nlm.nih.gov/9787515/

URL: https://journals.sagepub.com/doi/ pdf/10.1177/014556139807700909

8. Benjamin JS. Kabuki syndrome: Reversing Intellectual Disability by Promoting Open Chromatin. A dissertation submitted to Johns Hopkins University in conformity with the requirements for the degree of $\mathrm{PhD}$. Baltimore, Maryland, 2015;149 p.

View at: Publisher Site: https://jscholarship.library. jhu.edu/handle/1774.2/39652

URL: https://jscholarship.library.jhu.edu/bitstream/ handle/1774.2/39652/BENJAMIN-DISSERTATION-2016.pdf? sequence $=1$

9. Lim C, Jung S-T, Shin CH, Park MS, Yoo WJ, Chung CY, Choi IH , Ko JM, Cho T-J. Diagnosis and Management of Hip Dislocation in Patients with Kabuki Syndrome. Clinics in Ortho- pedic Surgery, 2019;11(4):474-81. DOI: 10.4055/ cios.2019.11.4.474

View at: Publisher Site: https://ecios.org/DOIx. php?id=10.4055/cios.2019.11.4.474

PubMed: https://pubmed.ncbi.nlm.nih.gov/31788172/ PubMed Central: https://www.ncbi.nlm.nih.gov/pmc/ articles/PMC6867925/

10. Shpargel KB, Mangini CL, Xie G, Ge K, Magnuson T. The KMT2D Kabuki syndrome histone methylase controls neural crest cell differentiation and facial morphology. Development. $2020 \mathrm{Jul}$ 17;147(21):dev187997. DOI: 10.1242/dev.187997

View at: Publisher Site: http://dev.biologists.org/ lookup/doi/10.1242/dev.187997

PubMed: https://pubmed.ncbi.nlm.nih. gov/32541010/

PubMed Central: https://www.ncbi.nlm.nih.gov/pmc/ articles/PMC7375479/

11. Serbati N, Nassereddine S, Dehbi H, Nadifi S. Clinical Heterogeneity of Kabuki Syndrome: Study of Moroccan Patients. Int. J. LifeSc. Bt \& Pharm. Res. 2012;1(1):68-74.

View at: Publisher Site: http://www.ijlbpr.com/ index.php? $\mathrm{m}=$ content $\& \mathrm{c}=$ index \& $\mathrm{a}=$ show $\&$ catid $=114 \& \mathrm{id}=452$

Article history

Received: 11.05.2021

Revision requested: 02.07.2021

Revision received: 19.08 .2021

Accepted: 24.09.2021

Published: 30.09.2021

\title{
МОЛЕКУЛЯРНО-ГЕНЕТИЧНІ АСПЕКТИ СИНДРОМУ ГРИМУ КАБУКІ. ОГЛЯД
}

\author{
${ }^{1}$ Ластівка І.В., ${ }^{2}$ Анцупова В.В., ${ }^{1}$ Бабінцева А.Х., ${ }^{3}$ Унгурян, 2 Ушко Я.А. \\ ${ }^{1}$ Буковинський держсавний медичний університет, Чернівиі, Украӥна \\ ${ }^{2}$ Національний медичний університет імені О.О.Богомольия, Київ, Украӥна \\ ${ }^{3}$ Чернівецький обласний перинатальний центр, Чернівиі, Украйна \\ antsupovavita@gmail.com
}

\begin{abstract}
Актуальність. Синдром гриму Кабукі (КС) - це рідкісне моногенне генетичне захворювання, що характеризується множинними вадами розвитку. Фенотип включає специфічні риси обличчя, скелетні та дерматогліфічні відхилення, розумову відсталість, низький зріст. Більшість випадків пов'язані з мутаціями de novo у генах KMT2D та KMD6A. Однак у $25 \%$ пацієнтів 3 КС генетична основа залишається невідомою, що свідчить про генетичну гетерогенність захворювання та спонукає до подальшого накоплення клінічного досвіду КС. В статті узагальнені сучасі дані щодо молекулярно-генетичних аспектів розвитку синдрому гриму Кабукі та описан власний клінічний випадок синдрому гриму Кабукі I типу.

Ціль: узагальнити дані про сучасні молекулярної-генетичні аспекти розвитку синдрому гриму Кабукі на прикладі клінічного випадку.

Матеріали та методи. Аналіз публікацій з міжнародних наукометричних електронних баз Scopus, PubMed за ключовими словами. Глибина пошуку - 15 років (2007-2021). Клінічний випадок синдрому гриму Кабукі з власної практики. Клініко-генеалогічні, молекулярно-генетичні, цитогенетичні, інструментальні методи дослідження.

Результати. За сучасними даними, розвиток синдрому гриму Кабукі обумовлений мутаціями гену KMT2D (MLL2), який належить до генів, що контролюють ембріогенез. KMT2D функціонує як промотор експресії інших генів та гену KDM6A; кодує великий мультидоменний протеїн, що взаємодіє з комплексом SET1/COMPASS. KDM6A є кофактором, фізично пов'язаним із комплексом KMT2D-COMPASS, та проявляє деметилазну активність в гістоні 3. Генні мутації KMT2D та KDM6A, пов`язані із КС, призводять до відсутності функціонування відповідного ферменту, що приводить до порушення метилювання гістонів та
\end{abstract}


активації специфічних генів у багатьох органах та тканинах організму. Залежно від виду мутації в генах KMT2D та KMD6A, виділяють два типи синдрому гриму Кабукі. КС 1-го типу з аутосомно-домінантним типом успадкування, обумовлений патогенними мутаціямі в гені $K M T 2 D$ в гетерозиготному стані на хромосомі 12 q13.12. У 70 \% хворих виявляють КС1. КС 2-го типу - Х-зчеплене захворювання, що розвивається в результаті гетерозиготної патогенної мутації в гені KDM6. У більшості випадків КС мутації є спорадичними, однак описані родини з передачею захворювання від батьків до дітей. У хворих з фенотиповими ознаками КС патогенні мутації виявляють в 75 \% випадків. Патогенні мутації в гені $K M T 2 D$ можуть бути виявлені в мозаїчній формі, а носій може передати цю мутацію нащадкам. Патогененні мутації не описані у фенотипово здорових людей.

Наводимо власне спостереження. Дівчинка 3 комбінованою уродженою вадою серця та множинними стигмами дизембріогенезу народилась на 36 тижні з вагою 2930, довжиною 49 см, за шкалою Апгар 8/8 балів від III планованої вагітності у батьків, які вже мали старшого здорового хлопчика. У зв'язку з множинними вадами розвитку дівчинці було проведено синдромологічну діагностику за допомогою програми «Face2gene»; запідозрений синдром гриму Кабукі. Молекулярно-генетичний аналіз виявив патогенну мутацію (c.11884C $>T(p . G \ln 3962 *)$ у гені KMT2D, який асоціюється з аутосомно-домінантним синдромом Кабукі 1 типу (MedGen UID: 893727).

Висновки. Синдром гриму Кабукі має клінічний та молекулярний поліморфізм. Більшість із зареєстрованих мутацій КMT2D виникають de novo i зустрічаються в епізодичних випадках. Описаний випадок демонструє молекулярно-позитивний синдром гриму Кабукі I типу. Ідентифікований варіант $c .11884 C>T(p . G \ln 3962 *)$ у гені KMT2D асоціюється з аутосомно-домінантним синдромом гриму Кабукі (MedGen UID: 893727). Верифікація діагнозу захворювання та профілактика КС у сибсів проводиться на основі результатів молекулярно-генетичного аналізу. Прогноз захворювання при цій патології залежить від тяжкості уражень серця та пошкодження інтелекту. Рання діагностика визначає тип та терміни терапевтичних втручань, має вирішальне значення для медико-генетичного консультування родини.

Ключові слова: синдром гриму Кабукі, специфічні риси обличчя, мутації генів $K M T 2 D, K M D 6 A$.

\section{МОЛЕКУЛЯРНО-ГЕНЕТИЧЕСКИЕ АСПЕКТЫ СИНДРОМА ГРИМА КАБУКИ. ОбЗОР}

\section{${ }^{1}$ Ластивка И.В., ${ }^{2}$ Анцупова В.В., ${ }^{1}$ Бабинцева А.Х., ${ }^{3}$ Унгурян, ${ }^{2}$ Уико Я.А.}

${ }^{1}$ Буковинский государственный медицинский университет, Черновцьь, Украина

${ }^{2}$ Национальний медицинский университет имени А.А. Богомольц̧а, Киев, Украина

${ }^{3}$ Черновецкий областной перинатальный цฺентр, Черновияы, Украина

antsupovavita@gmail.com

Актуальность. Синдром грима Кабуки (КС) - это редкое моногенное генетическое заболевание, характеризующееся множественными пороками развития. Фенотип включает специфические черты лица, скелетные и дерматоглифические отклонения, умственную отсталость, низкий рост. Большинство случаев связаны с мутациями de novo в генах KMT2D и KMD6A. Однако у $25 \%$ пациентов с КС генетическая основа остается неизвестной, что свидетельствует о генетической гетерогенности заболевания и побуждает к дальнейшему накопления клинического опыта КС. В статье обобщены современные данные по молекулярно-генетическим аспектам развития синдрома грима Кабуки и описан собственный клинический случай синдрома грима Кабуки I типа.

Цель: обобщить данные о современных молекулярно-генетических аспектах развития синдрома грима Кабуки на примере клинического случая.

Материалы и методы. Анализ публикаций из международных наукометрических электронных баз Scopus, PubMed по ключевым словам. Глубина поиска - 15 лет (2007-2021). Клинический случай синдрома грима Кабуки из собственной практики. Клинико-генеалогические, молекулярно-генетические, цитогенетические, инструментальные методы исследования.

Результаты. По современным данным, развитие синдрома грима Кабуки обусловлено мутациями гена KMT2D (MLL2), который относится к генам, контролирующим эмбриогенез. KMT2D функционирует как промотор экспрессии других генов и гена $K D M 6 A$; кодирует большой мультидоменный протеин, взаимодействует с комплексом SET1/COMPASS. KDM6A является кофактором, физически связанным с комплексом KMT2D-COMPASS, и проявляет деметилазную активность в гистоне 3. Генные мутации $K M T 2 D$ и $K D M 6 A$, связанные с КС, что приводит к отсутствию функционирования соответствующего фермента, приводит к нарушению метилирования гистонов и активации специфических генов во многих органах и тканях организма. В зависимости от вида мутации в генах $K M T 2 D$ и $K M D 6 A$, выделяют два типа синдрома грима Кабуки. КС 1-го типа с аутосомно-доминантным типом наследования, обусловлен патогенными мутациями в гене $K M T 2 D$ в гетерозиготном состоянии на хромосоме 12q13.12. У 70 \% больных обнаруживают КС1. КС 2-го типа - Х-сцепленное заболевание, развивающееся в результате гетерозиготной патогенной мутации в гене KDM6. В большинстве случаев КС мутации являются спорадическими, однако описаны семьи с передачей заболевания от родителей к детям. У больных с фенотипическими признаками КС патогенные мутации обнаруживают в 75 \% случаев. Патогенные мутации в гене $K M T 2 D$ могут быть обнаружены в мозаичной форме, а носитель может передать эту мутацию потомкам. Патогененные мутации не описаны у фенотипически здоровых людей.

Приводим собственное наблюдение. Девочка с комбинированным врожденным пороком сердца и множественными стигмами дизэмбриогенеза родилась на 36 неделе с весом 2930, длиной 49 см, по шкале Апгар 8/8 баллов от III планируемой беременности у родителей, которые уже имели старшего здорового мальчика. В связи с множественными пороками развития девочке была проведена синдромологическая диагностика с помощью программы «Face2gene»; заподозрен синдром грима Кабуки. Молекулярно-генетический анализ выявил патогенную мутацию (c.11884C>T (p.Gln3962 *) в гене KMT2D, который ассоциируется с аутосомно-доминантным синдромом Кабуки 1 типа (MedGen UID: 893727).

Выводы. Синдром грима Кабуки имеет клинический и молекулярный полиморфизм. Большинство из зарегистрированных мутаций $K M T 2 D$ возникают de novo и встречаются в эпизодических случаях. Описанный случай демонстрирует молекулярно-положительный синдром грима Кабуки I типа. Идентифицированный вариант $c .11884 C>T(p . G \ln 3962$ *) в гене KMT2D ассоциируется с аутосомно-доминантным синдромом грима Кабуки (MedGen UID: 893727). Верификация диагноза заболевания и профилактика КС у сибсов проводится на основе результатов молекулярно-генетического анализа. Прогноз заболевания при этой патологии зависит от тяжести поражений сердца и повреждения интеллекта. Ранняя диагностика определяет тип и сроки терапевтических вмешательств, имеет решающее значение для медико-генетического консультирования семьи.

Ключевые слова: синдром грима Кабуки, специфические черты лица, мутации генов KMT2D, KMD6A. 